DOI: https://doi.org/10.32839/2304-5809/2021-3-91-18

УДК 37.016:81’243]:165.194

Канюк О.С.

Ужгородський національний університет

\title{
КОГНІТИВНИЙ НАПРЯМ У МЕТОДИЦІ ВИКЛАДАННЯ ІНОЗЕМНОЇ МОВИ
}

\begin{abstract}
Анотація. У статі досліджено процес оволодіння іноземною мовою, збагачений когнітивною психологією та когнітивним підходом. Розглянуто перетворення навчання іноземної мови в усвідомлений навчальний процес, задіяння розумових здібностей учнів у когнітивному процесі. Досліджено комплекс вправ відповідно до цілей когнітивного напряму, які спрямовані на формування умінь і навичок у процесі вивчення англійської мови. Проаналізовано розвиток граматичних, лексичних і фонетичних навичок в учнів. Стаття присвячена особливості когнітивного підходу до навчання іноземної мови, а також аналізу основних принципів цього підходу.
\end{abstract}

Ключові слова: методика викладання, когнітивна лінгвістика, концепт, комплекс вправ, мовний матеріал, граматичні, лексичні і фонетичні навички.

Kaniuk Olesia Uzhhorod National University

\section{COGNITIVE DIRECTION IN THE METHODOLOGY OF TEACHING A FOREIGN LANGUAGE}

Summary. This study analyzes the process of mastering a foreign language, considers the transformation of foreign language learning into a conscious learning process, the use of mental abilities of students in the cognitive process. A set of exercises in accordance with the goals of the cognitive direction is researched, which are aimed at the formation of skills and abilities in the process of learning English. The development of grammatical, lexical and phonetic skills in students is analyzed. The article is devoted to the peculiarities of the cognitive approach to foreign language learning, as well as the analysis of the basic principles of this approach. The study considers the main provisions of cognitive linguistics, analyzes its relationship with the methods of teaching a foreign language. The possibilities of applying the concept in the learning process are also demonstrated. Through the use of the concept it becomes possible to improve the intercultural competence of the student. The article examines cognitive psychology, which is the psychology of cognitive processes. It is cognitive psychology that is concerned with the study of mental states and processes that characterize human behavior. Regarding cognitive linguistics, this study states that it is one of the areas of linguistics that explores the mechanism of knowledge transfer through language. This study considers the modern teacher as a specialist who must have all the tools of teaching methods, because cognitive linguistics and cognitive psychology turns the study of a foreign language into a conscious process, where an important role is played by the mental abilities of students. The possibilities of application of the concept in the educational process are determined, which allows to consider it as a source unit of learning, organization and selection of language material. The author explored the essence of cognitive-communicative methods of learning a foreign language, as well as its key aspects and principles, as the relevance of this research topic is gradually increasing. This method helps students to predict lexical material when constructing their own statements. Using a cognitive-communicative approach in the methodology of teaching a foreign language, you can solve various methodological issues related to the organization and sequence of learning language material.

Keywords: teaching methods, cognitive linguistics, concept, set of exercises, language material, grammatical, lexical and phonetic skills.

$\prod^{\circ}$ остановка проблеми. На теперішній час актуальним у процесі навчання іноземної мовою є те, що активно впроваджуються когнітивні та технології, адже їх застосування передбачає формування системи певних знань, умінь і навичок, і надає можливість учню сфрормувати конкретні компетенції.

Завдяки когнітивному підходу до вивчення іноземної мови, можливо накопичувати і впорядковувати теоретичні, лінгвокультурологічні знання, розвивати пізнавальні можливості особистості учня. Використовуючи когнітивний напрям у методиці викладання іноземної мови, можливо, підвищити ефективність використання набутих знань.

Аналіз останніх досліджень і публікацій. Проблема когнітивного підходу до навчання різним видам мовленневої діяльності та аспектам іноземної мови досліджувалася в ряді дисертацій, монографій, науково-методичних статей i наукових доповідей (Н.В. Баграмова, Н.В. Баришніков, Г.В. Слізарова, С.Ф. Шатілов, Т.Д. Шевченко, А.В. Щепілова, Ю.А. Ситнов, П.К. Бабинська, А.В. Баценко, М.Л. Гец та ін.).

Мета статті та їі завдання - дослідити когнітивний напрям у методиці викладання іноземної мови.

Виклад основного матеріалу та обгрунтування отриманих результатів дослідження. У розумінні В.З. Дем'янкова, когнітивізм - «погляд, згідно з яким людина повинна вивчатися як система переробки індрормації, а поведінка людини повинна описуватися і пояснюватися у внутрішніх станів людини» [2]. Дані стани проявляються фрізично, вони спостережувані і інтерпретуються як отримання, обробки, зберігання і мобілізації інформації для вирішення завдань. А оскільки вирішення цих за- 
вдань безпосередньо пов'язане з використанням мови, то мова опинилася в центрі уваги когнітивістів. Мова, за твердженням Г. Хармана, є головною темою в когнітивній науці, так як саме він відображає пізнання, виступаючи як основний засіб вираження думки, і тому вивчення мови - це непряме вивчення пізнання.

3 самого початку виникнення когнітивної науки особливу роль відводили психології та лінгвістиці, підкреслюючи тим самим особливе становище об'єктів їх аналізу - психіки, свідомості, мови - у самій мовній діяльності людини.

Когнітивна психологія - це психологія пізнавальних процесів; особливий напрямок в психології, пов'язаний 3 вивченням ментальних станів і ментальних процесів, що характеризують поведінку людини. Цей напрямок з'явився в американській науці як альтернатива домінуванню біхевіоральних концепцій, які заперечували роль свідомості і підходили до інтелекту, в основному, як до здатності навчатися шляхом проб і помилок. Когнітивна психологія вивчає, як люди отримують інформацію про світ, як ця інформація представляеться людиною, як вона зберігається в пам'яті і перетворюеться в знання i як ці знання впливають на нашу увагу i поведінку.

Серед найважливіших тем когнітивної психології - мова, яка вивчається тут як інтеріоризована система знань про мову, мовної компетенції, мовних уміннях і навичках, нерідко інтерпретуеться як система вроджених знань. Одним із завдань когнітивної психології $є$ створення такої когнітивної моделі мови і мовної, комунікативної діяльності, яка об'єднала б в інтегральній формі відомості про виробництво або породження мови 3 відомостями про її сприйняття i, нарешті, про їі розумінні х5ї.

Когнітивна лінгвістика - один з напрямків лінгвістики, що досліджує механізми вилучення, зберігання і передачі знань за допомогою мови. Виникнення когнітивної лінгвістики пов'язують з іменами Дж. Лакофрда i X. Томпсона. У центрі уваги когнітивної лінгвістики знаходиться мова як загальний когнітивний механізм, як когнітивний інструмент - система знаків, що грають роль в репрезентації (кодуванні) і в трансформації інформації [3]. Мова розглядається як основний засіб «фіксації, переробки і передачі знання і виступає в якості своєрідної системи різних упаковок знання» [4].

Концепт - внутрішньо організований. Його структура характеризуеться когнітивними ознаками, які визначаються за ступенем яскравості у свідомості певної конкретної людини й упорядковуються за польовим принципом.

Вивчення іноземних мов - процес довгий і непростий, що займає багато часу і сил. Тому вчителю необхідно використовувати сучасні інноваційні та креативні технології для того, щоб процес вивчення іноземної мови став більш цікавим. Важливо формувати в учнів уявлення про систему мови, розвивати вміння використовувати цю систему в мові.

При вивченні іноземної мови людина йде від розуміння його властивостей до його структури. В даному випадку варто поговорити про провід- ний когнітивний підхід в навчанні іноземної мови.

Когнітивність (лат. cognitio, «пізнання, вивчення, усвідомлення») - здатність до розумового сприйняття і переробки людиною зовнішньої інформащії. Отже, знання є результатом когнітивного процесу.

Завдання вчителя - створювати проблемні ситуащії для учнів для того, щоб вони відкривали нові знання самостійно (він не передає учням знання в готовому вигляді і не нав'язуе їх), пред'являє зразки іноземної мови, пропонує когнітивні прийоми, вчить учня застосовувати ті чи інші стратегії адекватно завданню, що стоїть перед ним. Таким чином, мова будуеться на основі когнітивної активності в процесі мовної практики в навчальному середовищі через взаємодію вчителя, учня і його однокласників. Процес вивчення мови приймає дослідницький і експериментальний характер.

Нижче представлені вправи, спрямовані на розвиток лексичної пам'яті, креативного мислення, здатності виводити нові слова на основі знайомих словотвірних моделей, розвиток мовної здогадки і прогнозування.

На практиці когнітивний підхід означає, що вчитель повинен забезпечити проходження учням певних стадій пізнавального процесу х1ї:

- аналіз вже наявних знань;

- спостереження нового;

- постановка нового завдання;

- висунення гіпотези;

- закріплення нового знання за допомогою наявних у учня стратегій;

- експериментальне використання нового знання.

Когнітивний підхід у навчанні іноземної мови вкрай необхідний. Крім розумового, він також сприяе духовному і соціальному розвитку учня. Оскільки даний підхід базуеться на отриманих при оволодінні рідною мовою учнями когнітивних уміннях, це значно прискорюе процес оволодіння іноземною мовою при трьох годинах на тиждень, які відводяться на вивчення іноземної мови в загальноосвітній школі, і в кінцевому підсумку веде до створення ситуації успіху в навчанні [4].

При застосуванні креативного напряму вдається домагатися кращого, якісного засвоєння знань. Для підтримки інтересу учнів до вивчення іноземної мови вчителям необхідно використовувати на своїх заняттях також фрагменти opiльмів, в тому числі анімаційних, англійською мовою (в залежності від віку учнів), елементи дебатів, рольових ігор, вікторин, для того, щоб діти розуміли, що теоретична частина і практична - складові єдиного процесу.

При вивченні англійської мови із використанням когнітивного напряму необхідно враховувати наступні напрями:

Граматична сторона мови

Необхідно ефрективне засвоєння граматичних явищ, засвоєних раніше рецептивно, у зв'язку 3 цим відбувається систематизування граматичного матеріалу [3]:

1. Поліпшення навичок розпізнавання і використання в мові пройдених раніше комунікативних і структурних типів речень; систе- 
матизування знань щодо складносурядних та складнопідрядних пропозицій, у тому числі умовних речень із ступенем ймовірності: ймовірні, малоймовірні і неймовірні: First, Second, Third Conditional.

2. Вироблення навичок розпізнання і використання в мові із конструкцією I wish... (I wish I had my own car), конструкцією so / such + that (I was so tired that forgot to call my mother), emфотичних це не так, як ви думаєте.

3. Поліпшення навичок розпізнання і використання в мові дієслів, представлених в найбільш поширених часових формах в дійсній заставі: Present Simple/Future Simple/Past Simple, Present / Past Continuous, Present / Past Perfect; модальні дієслова та їх еквіваленти.

4. Володіння ознаками і навичками розпізнавання і застосування в ситуаціях спілкування діеслів: Perfect Continuous / Past Perfect Continuous Present Simple Passive/Future Simple Passive/ Past Simple Passive/Present Perfect Passive.

5. Володіння ознаками і навичками розпізнавання в процесі читання дієслів в Past Perfect Passive / Future Perfect Passive; неособистих форм дієслів (Infinitive, Participle I i Gerund) без розрізнення їх фрункцій [3].

6. Розвиток навичок розпізнавання i застосування в мові різних граматичних засобів для формулювання майбутнього часу: Simple Future/to be going to/Present Continuous.

7. Поліпшення навичок використання визначеного / невизначеного / нульового артиклів; іменників в однині і множині (також і винятків).

8. Розвиток навичок розпізнавання і використання в мові особистих, присвійних, вказівних, невизначених, відносних, питальних займенників; прикметників і прислівників, в тому числі прислівників, які виражають кількість (many / much, few / a few, little / a little); кількісні та порядкові числівники.

Систематизування знань про фрункціональну важливість прийменників і поліпшення навичок їх використання: прийменників у dpразах, які виражають напрямок, час, місце дії; у тексті для додання йому цілісності, наприклад, прислівників (firstly, finally, at last, in the end, etc.).

Розглянемо вправи для розвитку лексичних навичок, матеріалом яких послужив розглянутий навчально-методичний комплекс [5], при цьому ми їх декілька трансформували відповідно до досліджуваної теми [5]:

- розділіться на пари по три-чотири людини, обговоріть наступні питання: 1. Which opinion from the comments above do you share? Why? 2 . Name another embarrassing situation that can happen in a family. Make 5-6 situations. 3. How would you cope with an embarrassing situation?

- придумайте діалог для бесіди з товаришем, використовуючи інформацію з тексту, а також включивши вашу особисту думку;

- розгляньте dротоградіiі і поясніть, хто і що зображено на вашу думку, які емоції відчувають персонажі?

- прослухайте діалог i продовжите думки підлітків;

- робота в групі, обговоріть тему: What happy / sad / boring moments are mentioned most often in your group?
- розгляньте фотоградію сім'ї, опишіть, якими якостями необхідно володіти для створення щасливої родини, поясніть на прикладі персонажів;

- розкажіть про сумні, щасливі моменти Вашого життя, що робить вас щасливим, що змушуе сумувати? Використовувати лексику уроку.

Розвиток фонетичних навичок мовлення

При знайомстві 3 фонетичними явищами пояснення обов'язково має супроводжуватися демонстрацією еталонів, які школярі чують від викладача або в аудіозапису, для створення умов, в яких навчаються безперервно чують звуки в той момент, коли відбувається пояснення їх артикуляції.

Тренування містить два типи вправ [4]:

- активні прослуховування зразків;

- усвідомлене повторення.

При формуванні та розвитку навичок вимови широко застосовуються такі організаційні форми: хорова, індивідуальна і парна.

Для посилення зверненості мови необхідно використовувати також режим парної роботи. За сигналом викладача учні повертаються один до одного і по черзі вимовляють слова (словосполучення, пропозиції), які містять засвоювані звуки.

Розглянемо вправи, спрямовані на розвиток фонетичних навичок, в даних вправах основним є правильна вимова і інтонація, які узгоджуються 3 вірним вибором лексем і граматично вірні [4]:

- прослухайте бесіду і заповніть прогалини словами 3 рамок (really, I believe, I think, but, you see, the fact is that..., I suppose...);

- розгляньте фотографіï і розкажіть, на який 3 них зображена кімната для сім'ї, поясніть чому;

- робота в парах, поділіться інформацією про те, чи є у вас сестри і брати, використовуючи вирази наведені у вправі;

- прочитайте текст і виберіть речення, яке найкраще описуе його зміст;

- прочитайте текст знову і дайте відповідь на питання, обговоріть їх зі своїм однокласником;

- прослухайте текст і заповніть порожні клітинки необхідним слово;

- виберіть одну з ситуацій і складіть до неї діалог з сусідом по парта;

- прослухайте бесіду підлітків і заповніть решту таблиці.

Висновки. В даний час педагогічні технології враховують безліч фракторів, які впливають на процес навчання, у зв'язку, з чим змінюеться і роль педагога в даному процесі. У світовій педагогічній науці на даний момент педагог розглядається як менеджер, який управляє активністю розвитку діяльності учнів. Дана ситуація передбачає необхідність володіння педагогом всім інструментарієм методів навчання, відповідно роль педагогічних технологій у досягненні високої якості освіти в запропонованих умовах зростає. Процес оволодіння іноземною мовою, збагачений даними когнітивної психології та когнітивного підходу, перетворюе навчання іноземної мови в усвідомлений навчальний процес, в якому на будь-якому етапі роботи повинні бути задіяні розумові здібності учнів. 


\section{Список літератури:}

1. Барышников В.Н. Когнитивный взгляд на технологию обучения иностранным языкам. Когнитивная парадигла (тезисы Междун. конфб.). Пятигорск : ПГЛУ, 2000. С. 10-13.

2. Выходцева Т.В. Использованию инновационных и когнитивных технологий в обучении грамматике на уроках иностранного языка. Молодой ученый. 2017. № 49 (183). С. 343-345.

3. Гін А.О. Прийоми педагогічної техніки. Вільний вибір. Відкритість. Діяльність. Ідеальність. Луганськ : Навчальна книга, 2004. 275 с.

4. Зонтова С.Є. Когнітивний підхід до навчання іншомовної лексики. Проблели сучасної педагогічної освіти : Зб. наук. праць. Ялта : РВВ КГУ, 2005. Вип. 8, ч. 2. С. 89-93.

5. Солсо Р. Когнитивная психология. Питер, 2006. 588 с.

\section{References:}

1. Baryshnikov V.N. (2000) Cognitive view on the technology of teaching foreign languages. Cognitive paradigm (theses of the International Conference). Pyatigorsk: PGLU, pp. 10-13.

2. Vykhodtseva T.V. (2017) The use of innovative and cognitive technologies in teaching grammar at foreign language lessons. Young scientist, no. 49 (183), pp. 343-345.

3. Gin A.O. (2004) Priyomi pedagogichnoi tekhniki. Vilny vibir. Vakreste. Operation. Dealnet. Lugansk: Navchalna kniga, $275 \mathrm{p}$.

4. Zontova S.Ye. (2005) Cogntive pdhd to navchannya hamono vocabulary. Problems of modern pedagogical education: Collection of scientific works. Yalta: RVV KSU, vol. 8, part 2, pp. 89-93.

5. Solso R. (2006) Cognitive psychology. Peter, 588 p. 